Theories \& Applications, the International Edition

Printed Version: (ISSN 2090-5262)

Online Version: (ISSN 2090-5270)

July 2013, Volume 3, No. 2 Pages (71 - 88)

\title{
Proposed Implementation Plan for Development of Administrative Directorate of Youth and Sport in Sharkia Province Related to Requirements of Six Sigma Quality Standards Application
}

\author{
Ayman Ali Abd El-Hameed El-Shaer*
}

\begin{abstract}
This research aims to create a proposed implementation plan for development of administrative Directorate of Youth and Sport in Sharkia province related to requirements of Six Sigma quality standards application, Descriptive survey method was used as to suitability for the research procedures. The researcher selected (174) staff members, research community-style comprehensive inventory of Directorate of Youth and Sports in Sharkia and departments, twenty four (24) staff members have been excluded for the pilot study, the research sample became (150) staff members. Results: there are statistically significant of value of Ka2 of sample response to (1) senior management's contribution towards administrative development related to requirements of Six Sigma quality standards application. (2) Availability of training for administrative development related to requirements of Six Sigma quality standards application. (3) Suitability of information systems in administrative development related to requirements of Six Sigma quality standards application. (4) Presence extent of teams work for administrative development related to requirements of Six Sigma quality standards application. (5) Cooperation departments and divisions extent to develop administrative development related to requirements of Six Sigma quality standards application at $p<.(2,0.05)$.
\end{abstract}

Keywords: implementation plan - Six Sigma strategy.

\section{Introduction}

$\mathrm{W}$ ithout a strategic quality plan, an enormous amount of time, money, and effort will be wasted by the organization dealing with faulty designs, manufacturing defects, field failures, and customer complaints. Quality planning involves identifying customers, both external and those that operate internal to the business, and identifying their needs (this is sometimes called listening to the voice of the customer). Then product or services that meet or exceed customer expectations must be developed. The Organizations must then determine how these products and services will be realized. Planning for quality improvement on a specific, systematic basis is also a vital part of this process. (Burr, I.W., 1996)

\footnotetext{
* Assistant Professor at Sports management and Leisure Department, Faculty of Physical Education-(male), Zagazig University, Egypt.
}

Six Sigma has gained an avid following among executives and managers for its ability to reduce cycle time, eliminate product defects, and dramatically increase customer involvement and satisfaction. But Six Sigma can't work without widespread employee involvement and commitment. (Peter Pande, Lawrence Holpp, 2002).

Six Sigma is not confined just to manufacturing industry, rather it is equally applicable to service industry. (Antony J, et. al., 2007).

Six Sigma consists of a set of statistical methods for systemically analyzing processes to reduce process variation, which are sometimes used to support and guide organizational continual improvement activities. Six Sigma's toolbox of statistical process control and analytical techniques are being used by some companies to assess process quality and waste areas to which other lean methods can be applied as solutions. Six Sigma is also being used to further drive 
productivity and quality improvements in lean operations. (Hahn, G., 2001).

Much of the quality management research to date has found that quality management is a multidimensional construct which is composed of multiple quality practices. These quality practices have different functions and roles regarding continuous improvement. For example, a typical quality practice - workforce management - is to use the entire capacity of workers and to encourage employee commitment to organizational continuous improvement efforts. Workforce management emphasizes the organizational and people side of quality management and uses a variety of techniques to facilitate changes, such as employee participation in decisions, employee recognition, teamwork, and the use of effective communications to create an awareness of organizational goals. Another typical quality practice - process management - is concerned with using statistical and scientific techniques to reduce process variation, which represents the methodological and technical side of quality management (Robbins, Zu Fredendall, 2006).

The importance of this study because of its modernity in the Arab Management, Being a developing style seeks to raise the performance level and error handling in scientific ways which lead eventually to efficiency and quality of performance and rapid achievement.

This research aims to create a proposed implementation plan for development of administrative Directorate of Youth and Sport in Sharkia province related to requirements of Six Sigma quality standards application which are:

1. senior management's contribution towards administrative development
2. availability of training for administrative development

3. suitability of information systems in administrative development

4. cooperation departments and divisions extent to develop administrative development

5. presence extent of teams work for administrative development

\section{Hypotheses}

1. How senior management's contribution towards administrative development of Department of Youth and Sports in Sharkia related to requirements of Six Sigma quality standards application?

2. What is availability of training for administrative development of Department of Youth and Sports in Sharkia related to requirements of Six Sigma quality standards application?

3. What is the suitability of information systems in administrative development of Department of Youth and Sports in Sharkia related to requirements of Six Sigma quality standards application?

4. What is the presence extent of teams work for administrative development of Department of Youth and Sports in Sharkia related to requirements of Six Sigma quality standards application?

5. What are cooperation departments and divisions extent to develop administrative development of Department of Youth and Sports in Sharkia related to requirements of Six Sigma quality standards application?

6. What is the content of the proposed operational plan for the development of administrative development of Department of Youth and Sports in Sharkia related to requirements of Six Sigma quality standards application? 


\section{Sample and Data Collection}

Table (1)

Subject characteristics

\begin{tabular}{|c|c|c|c|c|}
\hline Sample & Number of agencies & Number of employees & Exploratory sample & Basic sample \\
\hline Cabinet of the Directorate & 23 & 410 & 7 & 59 \\
\hline Sub departments & 17 & 340 & 5 & 36 \\
\hline Urban youth centres & 25 & 378 & 8 & 30 \\
\hline Sports clubs & 44 & 245 & 4 & 25 \\
\hline \multicolumn{2}{|r|}{} & 1373 & 24 & 150 \\
\hline
\end{tabular}

Descriptive survey method was used as to suitability for the research procedures. Researcher chooses the research community by intentional way from Cabinet workers in the Directorate of Youth and Sports in Sharkia and departments subsidiary.

The researcher selected (174) staff members, research community-style comprehensive inventory of Directorate of Youth and Sports in Sharkia and departments, twenty four (24) staff members have been excluded for the pilot study, the research sample became (150) staff members (table 1).

\section{Data Collection}

Survey for questionnaire axes of the administrative development of Department of Youth and Sports in Sharkia related to requirements of Six Sigma quality standards application were used to measure the reality of administrative development.

Researcher designed questionnaire of the administrative development of Department of Youth and Sports in Sharkia related to requirements of Six Sigma quality standards application using reference survey for questionnaire axes as shown in table (2). 
Table (2)

Reference survey for questionnaire axes of the administrative development of Department of Youth and Sports in Sharkia related to requirements of Six Sigma quality standards application

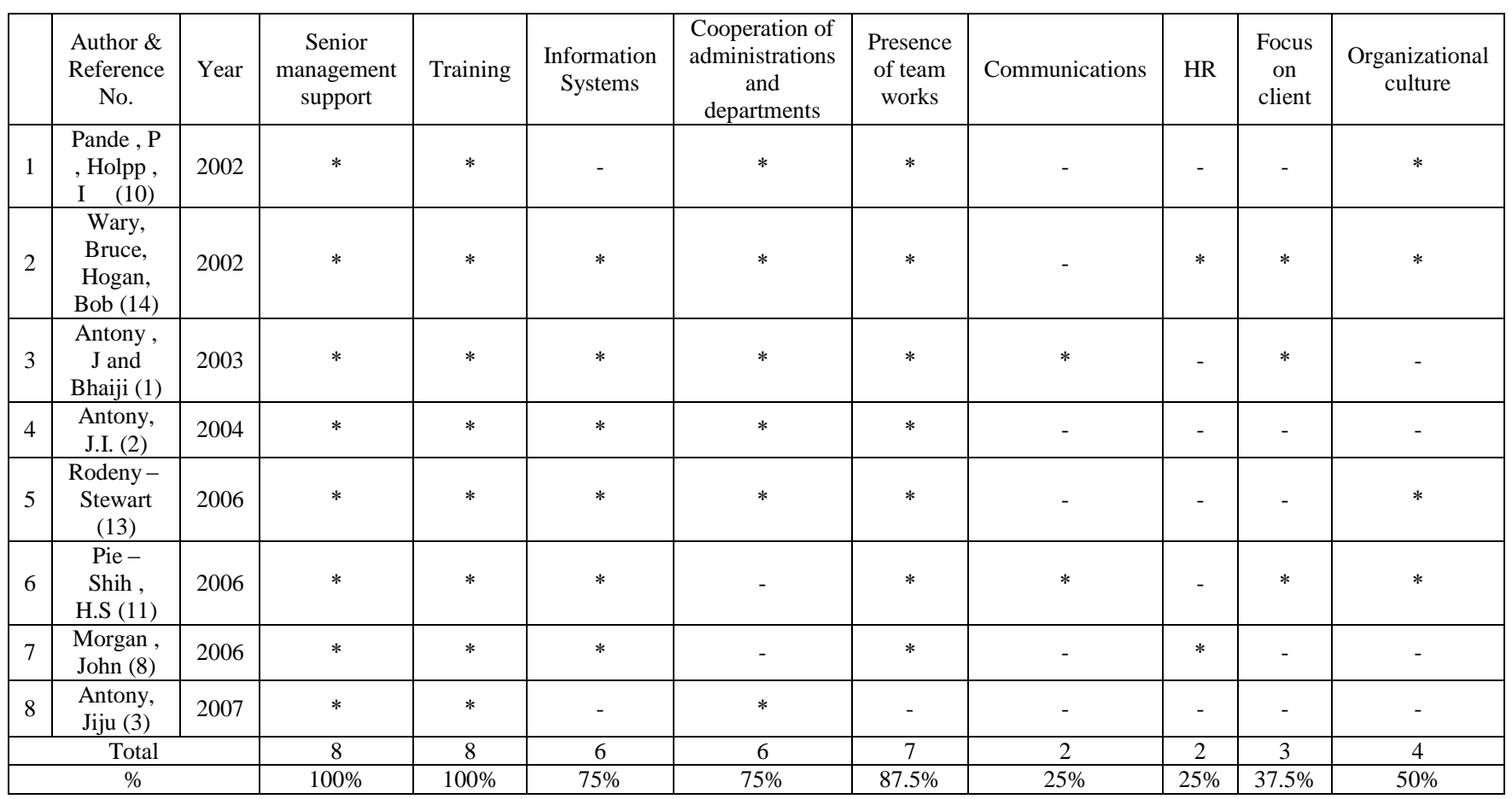

Table (2) shows reference survey for questionnaire axes of the administrative development of Department of Youth and Sports in Sharkia related to requirements of Six Sigma quality standards application, minimum
(70\%) of frequency percentage were used to select questionnaire axes.

These axes were inside questionnaire, axes were evaluated by experts in sport management, minimum $(80 \%-100 \%)$ of frequency percentage were used to select axes as shown in table (3).

Table (3)

Agreement of experts about questionnaire axes of the administrative development of Department of Youth and Sports in Sharkia related to requirements of Six Sigma quality standards application N=10

\begin{tabular}{|c|c|c|c|}
\hline serial & axes & $\begin{array}{c}\text { Agreement of } \\
\text { experts }\end{array}$ & Percentage \\
\hline 1 & $\begin{array}{c}\text { senior management's contribution towards administrative } \\
\text { development related to requirements of Six Sigma quality } \\
\text { standards application }\end{array}$ & 10 & $100 \%$ \\
\hline 2 & $\begin{array}{c}\text { availability of training for administrative development } \\
\text { related to requirements of Six Sigma quality standards } \\
\text { application }\end{array}$ & 10 & $100 \%$ \\
\hline 3 & $\begin{array}{c}\text { suitability of information systems in administrative } \\
\text { development related to requirements of Six Sigma quality } \\
\text { standards application }\end{array}$ & 10 & $100 \%$ \\
\hline 4 & $\begin{array}{c}\text { cooperation departments and divisions extent to develop } \\
\text { administrative development related to requirements of Six } \\
\text { Sigma quality standards application }\end{array}$ & 10 & $100 \%$ \\
\hline 5 & $\begin{array}{c}\text { presence extent of teams work for administrative } \\
\text { development related to requirements of Six Sigma quality } \\
\text { standards application }\end{array}$ & 10 & $100 \%$ \\
\hline
\end{tabular}

Researcher designed questionnaire proposed management to delete, add or redesign phrases. phrases, phrases evaluated by experts in sport 
Table (4)

Agreement of experts about phrases selection of questionnaire axes of the administrative development of Department of Youth and Sports in Sharkia related to requirements of Six Sigma quality standards application N=10

\begin{tabular}{|c|c|c|c|c|c|c|c|c|c|}
\hline serial & Percentage & serial & Percentage & serial & Percentage & serial & Percentage & serial & Percentage \\
\hline \multicolumn{10}{|c|}{$\begin{array}{c}\text { 1st axis: senior management's contribution towards administrative development related to requirements of Six } \\
\text { Sigma quality standards application }\end{array}$} \\
\hline 1 & $100 \%$ & 2 & $90 \%$ & 3 & $40 \%$ & 4 & $100 \%$ & 5 & $100 \%$ \\
\hline 6 & $90 \%$ & 7 & $90 \%$ & 8 & $100 \%$ & 9 & $80 \%$ & 10 & $90 \%$ \\
\hline 11 & $80 \%$ & 12 & $80 \%$ & & & & & & \\
\hline \multicolumn{10}{|c|}{$\begin{array}{l}\text { 2nd axis: availability of training for administrative development related to requirements of Six Sigma quality } \\
\text { standards application }\end{array}$} \\
\hline 13 & $90 \%$ & 14 & $90 \%$ & 15 & $80 \%$ & 16 & $40 \%$ & 17 & $80 \%$ \\
\hline 18 & $100 \%$ & 19 & $80 \%$ & 20 & $90 \%$ & 21 & $90 \%$ & 22 & $40 \%$ \\
\hline \multicolumn{10}{|c|}{$\begin{array}{l}\text { 3rd axis: suitability of information systems in administrative development related to requirements of Six Sigma } \\
\text { quality standards application }\end{array}$} \\
\hline 23 & $100 \%$ & 24 & $90 \%$ & 25 & $90 \%$ & 26 & $90 \%$ & 27 & $100 \%$ \\
\hline 28 & $100 \%$ & 29 & $30 \%$ & 30 & $100 \%$ & 31 & $100 \%$ & 32 & $80 \%$ \\
\hline 33 & $50 \%$ & 34 & $100 \%$ & & & & & & \\
\hline \multicolumn{10}{|c|}{$\begin{array}{l}\text { 4th axis: cooperation departments and divisions extent to develop administrative development related to } \\
\text { requirements of Six Sigma quality standards application }\end{array}$} \\
\hline 35 & $100 \%$ & 36 & $90 \%$ & 37 & $100 \%$ & 38 & $100 \%$ & 39 & $90 \%$ \\
\hline 40 & $100 \%$ & 41 & $80 \%$ & 42 & $100 \%$ & 43 & $100 \%$ & 44 & $100 \%$ \\
\hline 45 & $90 \%$ & 46 & $100 \%$ & 47 & $100 \%$ & & & & \\
\hline \multicolumn{10}{|c|}{$\begin{array}{l}\text { 5th axis: presence extent of teams work for administrative development related to requirements of Six Sigma } \\
\text { quality standards application }\end{array}$} \\
\hline 48 & $80 \%$ & 49 & $100 \%$ & 50 & $80 \%$ & 51 & $80 \%$ & 52 & $100 \%$ \\
\hline 53 & $100 \%$ & 54 & $80 \%$ & 55 & $100 \%$ & 56 & $100 \%$ & 57 & $40 \%$ \\
\hline 58 & $100 \%$ & & & & & & & & \\
\hline
\end{tabular}

Table (4) shows Agreement of experts about phrases selection of questionnaire axes of the administrative development of Department of Youth and Sports in Sharkia related to requirements of Six Sigma quality standards application, minimum (70\%) of frequency

percentage were used to select phrases. Numbers of final phrases were (52).

Table (5) shows numbers of questionnaire phrases in its principled form, Number of deletions and Figures of deletions according to expert opinions' percentage.

Table (5)

Number of questionnaire phrases in its principled form, Number of deletions and Figures of deletions according to expert opinions' percentage

\begin{tabular}{|c|c|c|c|c|}
\hline serial & axes & $\begin{array}{c}\text { Number of } \\
\text { phrases }\end{array}$ & $\begin{array}{c}\text { Number of } \\
\text { deletions }\end{array}$ & $\begin{array}{c}\text { Figures of } \\
\text { deletions }\end{array}$ \\
\hline 1 & $\begin{array}{c}\text { senior management's contribution towards administrative } \\
\text { development related to requirements of Six Sigma quality } \\
\text { standards application }\end{array}$ & 12 & 1 & 3 \\
\hline 2 & $\begin{array}{c}\text { availability of training for administrative development } \\
\text { related to requirements of Six Sigma quality standards } \\
\text { application }\end{array}$ & 10 & 2 & 29,33 \\
\hline 3 & $\begin{array}{c}\text { suitability of information systems in administrative } \\
\text { development related to requirements of Six Sigma quality } \\
\text { standards application }\end{array}$ & 12 & 22 \\
\hline 4 & $\begin{array}{c}\text { cooperation departments and divisions extent to develop } \\
\text { administrative development related to requirements of Six } \\
\text { Sigma quality standards application }\end{array}$ & 13 & ---- & -2 \\
\hline 5 & $\begin{array}{c}\text { presence extent of teams work for administrative } \\
\text { development related to requirements of Six Sigma quality } \\
\text { standards application }\end{array}$ & 11 & 1 & 57 \\
\hline
\end{tabular}


Table (6)

Questionnaire axes of the administrative development of Department of Youth and Sports in Sharkia related to requirements of Six Sigma quality standards application \& phrases number which belong to

\begin{tabular}{|c|c|c|}
\hline serial & axes & $\begin{array}{c}\text { Total } \\
\text { numbers of } \\
\text { phrases }\end{array}$ \\
\hline 1 & $\begin{array}{c}\text { senior management's contribution towards administrative development related to requirements } \\
\text { of Six Sigma quality standards application }\end{array}$ & 11 \\
\hline 2 & $\begin{array}{c}\text { availability of training for administrative development related to requirements of Six Sigma } \\
\text { quality standards application }\end{array}$ & 8 \\
\hline 3 & $\begin{array}{c}\text { suitability of information systems in administrative development related to requirements of Six } \\
\text { Sigma quality standards application }\end{array}$ & 10 \\
\hline 4 & $\begin{array}{c}\text { cooperation departments and divisions extent to develop administrative development related to } \\
\text { requirements of Six Sigma quality standards application }\end{array}$ & 13 \\
\hline 5 & $\begin{array}{c}\text { presence extent of teams work for administrative development related to requirements of Six } \\
\text { Sigma quality standards application }\end{array}$ & 10 \\
\hline & Total & 52 \\
\hline
\end{tabular}

Final questionnaire axes of the administrative The researcher applied the test method development of Department of Youth and Spearman \& Brown to calculate correlation of Sports in Sharkia related to requirements of Six phrases, (Cronbach's alpha) to calculate stability Sigma quality standards application \& phrases of phrases, ranging from the correlation number which belong to (table 6).

This study used a discrete, three-point scale with end points of strongly disagree $(=$ no) and strongly agree (= yes) to measure the constructs. The items to measure the quality practices associated with Six Sigma implementation were adapted from prior empirical research on evaluating quality practices.

\section{Pilot Study}

The researcher conducted the survey on a sample of (24) staff members from the same research community and outside the basic sample in the period from 22/04/2012 to 01/05/2012.

\section{Scientific Processing of the Test I. The Stability Coefficient} coefficient between $(0.756,0.885)$ which indicates the high stability of the variables under consideration. Correlation coefficient of every degree of axis and total degree of questionnaire ranging between $(0.768,0.899)$ which indicates the high stability of the variables under consideration.

\section{The Factor of Honesty}

Internal consistency and sincerity was used, it transpired that the internal consistency of significant Scientific processing of phrases, to learn which shows the sincerity of the phrases under discussion.

\section{Basic Study}

The researcher performed the survey on 07/05/2012 up to 21/05/2012, Started by applying questionnaire survey. 
Table (7)

Frequency, percentage, value of Ka2 and phrases rank of sample response to 1st axis: senior management's contribution towards administrative development related to requirements of Six Sigma quality standards application $N=150$

\begin{tabular}{|c|c|c|c|c|c|c|c|c|c|c|c|}
\hline \multirow[b]{2}{*}{$\mathbf{S}$} & \multirow[b]{2}{*}{ Phrases } & \multicolumn{2}{|c|}{ Yes } & \multicolumn{2}{|c|}{ Rather } & \multicolumn{2}{|c|}{ No } & \multirow[b]{2}{*}{ 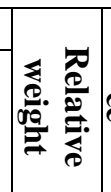 } & \multirow[b]{2}{*}{ (E) } & \multirow[b]{2}{*}{$\mathbb{N}_{N}^{T}$} & \multirow[b]{2}{*}{ 宽 } \\
\hline & & 草 & $\frac{*}{*}$ & 草 & $\frac{*}{*}$ & $\stackrel{*}{*}$ & $\frac{*}{*}$ & & & & \\
\hline 1 & $\begin{array}{l}\text { There are seriously from senior } \\
\text { management of the Directorate of } \\
\text { disposing old ways and search for } \\
\text { new sophisticated methods. }\end{array}$ & 99 & $66 \%$ & 27 & $18 \%$ & 24 & $16 \%$ & 375 & 83.33 & $72.12 *$ & $1^{\text {st }}$ \\
\hline 2 & $\begin{array}{l}\text { Modern technologies of senior } \\
\text { management availability of the } \\
\text { Directorate needed to raise } \\
\text { performance level and business } \\
\text { achievement. }\end{array}$ & 21 & $14 \%$ & 99 & $66 \%$ & 30 & $20 \%$ & 291 & 64.67 & $72.84^{*}$ & $5^{\text {th }}$ \\
\hline 3 & $\begin{array}{l}\text { Senior management encourages to } \\
\text { get rid of unnecessary steps in the } \\
\text { work. }\end{array}$ & 30 & $20 \%$ & 90 & $60 \%$ & 30 & $20 \%$ & 300 & 66.67 & $48.00^{*}$ & $4^{\text {th }}$ \\
\hline 4 & $\begin{array}{l}\text { Senior management gives the } \\
\text { opportunity to participate in the } \\
\text { efforts to improve performance. }\end{array}$ & 51 & $34 \%$ & 84 & $56 \%$ & 15 & $10 \%$ & 336 & 74.67 & $47.64 *$ & $3^{\text {rd }}$ \\
\hline 5 & $\begin{array}{c}\text { Senior management put precise } \\
\text { criteria to measure performance } \\
\text { level. }\end{array}$ & 12 & $8 \%$ & 96 & $64 \%$ & 42 & $28 \%$ & 270 & 60.00 & $72.48^{*}$ & $9^{\text {th }}$ \\
\hline 6 & $\begin{array}{l}\text { Dependent senior management } \\
\text { financial allocations to improve the } \\
\text { quality of performance. }\end{array}$ & 15 & $10 \%$ & 42 & $28 \%$ & 93 & $62 \%$ & 222 & 49.33 & $62.76^{*}$ & $10^{\text {th }}$ \\
\hline 7 & $\begin{array}{l}\text { Senior management development } \\
\text { praising the achievements at work. }\end{array}$ & 69 & $46 \%$ & 54 & $36 \%$ & 27 & $18 \%$ & 342 & 76.00 & $18.12^{*}$ & $2^{\text {nd }}$ \\
\hline 8 & $\begin{array}{l}\text { Senior management reward } \\
\text { outstanding in work. }\end{array}$ & 24 & $16 \%$ & 90 & $60 \%$ & 36 & $24 \%$ & 288 & 64.00 & $49.44^{*}$ & $7^{\text {th }}$ \\
\hline 9 & $\begin{array}{l}\text { Senior management benefit from } \\
\text { developmental studies and visions } \\
\text { for methods development of work } \\
\text { on an ongoing basis. }\end{array}$ & 18 & $12 \%$ & 96 & $64 \%$ & 36 & $24 \%$ & 282 & 62.67 & $66.72 *$ & $8^{\text {th }}$ \\
\hline 10 & $\begin{array}{l}\text { Senior management allows dialogue } \\
\text { in front of non-workers convinced } \\
\text { modern methods of development } \\
\text { and try to persuade them. }\end{array}$ & 18 & $12 \%$ & 21 & $14 \%$ & 111 & $74 \%$ & 207 & 46.00 & $111.72 *$ & $11^{\text {th }}$ \\
\hline 11 & $\begin{array}{c}\text { Senior management allows } \\
\text { applications of modern and } \\
\text { advanced administrative methods of } \\
\text { the affiliated Directorate. }\end{array}$ & 15 & $10 \%$ & 111 & $74 \%$ & 24 & $16 \%$ & 291 & 64.67 & $112.44 *$ & $\begin{array}{c}5^{\text {th }} \\
\text { Repeater }\end{array}$ \\
\hline
\end{tabular}

* Significantly different at $p<.(2,0.05)=5.99$

** Frequency

**** Percentage

Table (7) shows statistically significant of value of $\mathrm{Ka} 2$ of sample response to axis: senior management's contribution

towards administrative development related to requirements of Six Sigma quality standards application at $\mathrm{p}<.(2,0.05)$, value of calculated $\mathrm{Ka} 2$ ranged between $(18.12,112.44)$ and value of relative weight ranged between phrases $(207$, 375).

Percentage of phrases answered (yes) ranged between $(8 \%, 66 \%)$, percentage of phrases answered (rather) ranged between (14\%, 74\%), and percentage of phrases answered (no) ranged between $(10 \%, 74 \%)$. 
Table (7) shows statistically significant of all phrases of axis: senior management's contribution towards administrative development related to requirements of Six Sigma quality standards application, value of calculated $\mathrm{Ka} 2$ ranged between $(18.12,112.44)$ at $\mathrm{p}<.(2,0.05)$.

Administrative development begins from senior leadership, support of senior management for Sigma Six is a prerequisite for success of its applications, seriousness and enthusiasm of senior management contribute the applications of modern management methods, and disposal of old management methods, that assets the fixed conviction of management development importance through advanced administrative systems ensure output optimizing, attention of Directorate as a system from the simplest to the most complex operations.

Leader alone cannot delegate Sigma Six, Sigma Six requires support from senior management and regulatory environment provision positively which stimulate employees to production process, when leader has a firmly convinced of importance of Sigma Six application and participate actively in all levels of management, that conveys enthusiasm to the rest of all staff members, so the leader is a positive impetus within the organization. Six sigma strategy places an unprecedented importance on strong and passionate leadership and the support required for its successful deployment (Grog Brue, 2002).

hierarchical organizing has no role on the quality practitioners in Six Sigma (Robbins \& $\mathrm{Zu}$ Fredendall, 2006), these results on line with (Rodeny - Stewart, 2006) that improved production processes, costs reduction and disposal unnecessary activities of construction process are requirements of Six Sigma application. Support and commitment of senior management and changing the organizational culture instrumental have an important role in success of operation of applying Six Sigma (Antony, Bhaiji, 2003).

Table (8)

Frequency, percentage, value of Ka2 and phrases rank of sample response to 2nd axis: availability of training for administrative development related to requirements of Six Sigma quality standards application N=150

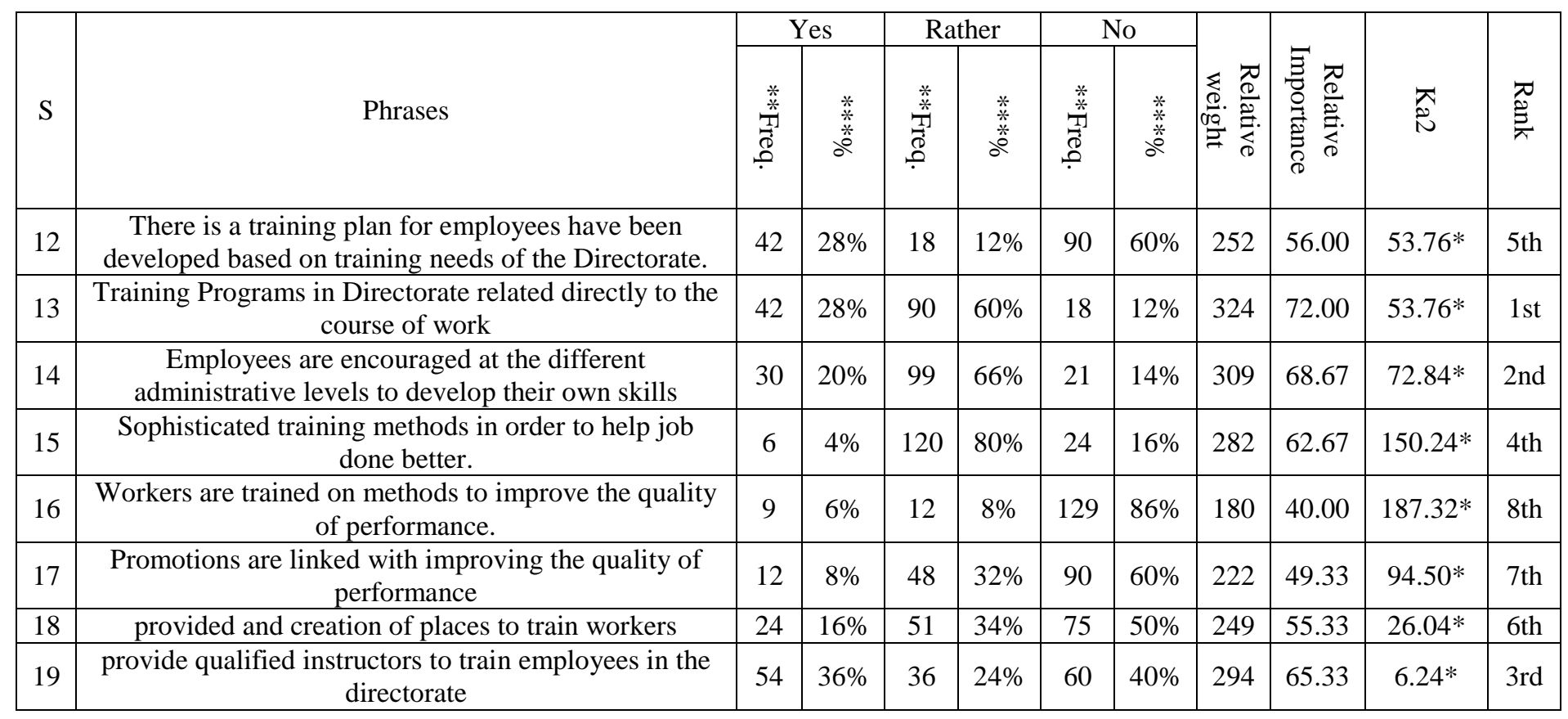

* Significantly different at $p<.(2,0.05)=5.99$

** Frequency

**** Percentage

Table (8) shows statistically significant of value of $\mathrm{Ka} 2$ of sample response to axis: availability of training for administrative development related to requirements of Six Sigma quality

standards application at $\mathrm{p}<.(2,0.05)$, value of calculated Ka2 ranged between $(6.24,187.32)$, and value of relative weight ranged between phrases $(180,324)$. 
Percentage of phrases answered (yes) ranged between $(4 \%, 36 \%)$, percentage of phrases answered (rather) ranged between $(8 \%, 80 \%)$, and percentage of phrases answered (no) ranged between $(12 \%, 86 \%)$.

Table (8) shows statistically significant of all phrases of axis: availability of training for administrative development related to requirements of Six Sigma quality standards application, value of calculated $\mathrm{Ka} 2$ ranged between $(6.24,187.32)$ at $\mathrm{p}<.(2,0.05)$.

Researcher attribute this results to the entity of workers encouraging in management levels in order to develop their own skills, but not as required development level, training programs are focusing on main work only in order to perform required tasks only, also non training on quality improving ways of performance due to weakness of awareness of quality systems importance.

The goal is to get the maximum return on Six Sigma investment by spreading it throughout company, continuing to train employees in the Six Sigma methodology and tools to lead process improvement teams, and sustaining the exponential gains you achieve by keeping it going (Kai Yang and Basem S. Elhaik, 2003).

These results are on line with (Robbins, $\mathrm{Zu}$ Fredendall, 2006) in the importance of guidance, groups organizational, development and rational practitioners' quality in Six Sigma. Applying of Six Sigma is improving performance level (Morgan - John, 2006). Training is one of elements which have a basic and important role in success of operation of applying Six Sigma (Antony, Bhaiji, 2003).

Table (9)

Frequency, percentage, value of Ka2 and phrases rank of sample response to 3rd axis: suitability of information systems in administrative development related to requirements of Six Sigma quality standards application $N=150$

\begin{tabular}{|c|c|c|c|c|c|c|c|c|c|c|c|}
\hline \multirow[b]{2}{*}{$\mathrm{S}$} & \multirow[b]{2}{*}{ Phrases } & \multicolumn{2}{|c|}{ Yes } & \multicolumn{2}{|c|}{ Rather } & \multicolumn{2}{|c|}{ No } & \multirow{2}{*}{ 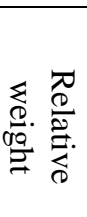 } & \multirow{2}{*}{ 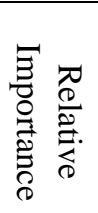 } & \multirow[b]{2}{*}{ 胥 } & \multirow[b]{2}{*}{ 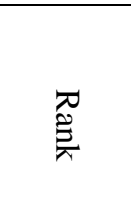 } \\
\hline & & $\frac{*}{*}$ & $\begin{array}{c}* \\
\frac{*}{*} \\
\stackrel{*}{*}\end{array}$ & 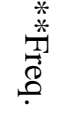 & $\frac{*}{*}+\frac{*}{*}$ & 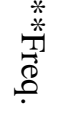 & $\frac{*}{\frac{*}{*}}$ & & & & \\
\hline 20 & $\begin{array}{l}\text { Availability in the Directorate strong } \\
\text { information and sophisticated infrastructure } \\
\text { linked to all departments and divisions. }\end{array}$ & 51 & $34 \%$ & 69 & $46 \%$ & 30 & $20 \%$ & 321 & 71.33 & $15.24 *$ & $3 r d$ \\
\hline 21 & $\begin{array}{l}\text { Information Infrastructure contributes } \\
\text { improving performance quality. }\end{array}$ & 63 & $42 \%$ & 57 & $38 \%$ & 30 & $20 \%$ & 333 & 74.00 & $12.36^{*}$ & $1 \mathrm{st}$ \\
\hline 22 & $\begin{array}{l}\text { There are modern databases in Directorate } \\
\text { help in making decision. }\end{array}$ & 18 & $12 \%$ & 123 & $82 \%$ & 9 & $6 \%$ & 309 & 68.67 & $160.68 *$ & 4 th \\
\hline 23 & $\begin{array}{l}\text { Work is done through computerized } \\
\text { communication. }\end{array}$ & 24 & $16 \%$ & 99 & $66 \%$ & 27 & $18 \%$ & 297 & 66.00 & $72.12 *$ & 7 th \\
\hline 24 & $\begin{array}{l}\text { There is an ongoing review of information } \\
\text { systems to correct mistakes. }\end{array}$ & 33 & $22 \%$ & 33 & $22 \%$ & 84 & $56 \%$ & 249 & 55.33 & $34.68 *$ & 9th \\
\hline 25 & $\begin{array}{l}\text { There is electronic network in Directorate } \\
\text { helps in performance guiding. }\end{array}$ & 27 & $18 \%$ & 30 & $20 \%$ & 93 & $62 \%$ & 234 & 52.00 & $55.56 *$ & 10th \\
\hline 26 & $\begin{array}{l}\text { There are alternative ways to get job } \\
\text { completion in case of faults. }\end{array}$ & 24 & $16 \%$ & 105 & $70 \%$ & 21 & $14 \%$ & 303 & 67.33 & $90.84 *$ & 6 th \\
\hline 27 & $\begin{array}{l}\text { Directorate of Youth and Sports in Sharkia } \\
\text { Used modern means of communication to } \\
\text { report references for its regions. }\end{array}$ & 27 & $18 \%$ & 102 & $68 \%$ & 21 & $14 \%$ & 306 & 68.00 & $81.48 *$ & 5 th \\
\hline 28 & $\begin{array}{l}\text { Directorate have a human possibilities to } \\
\text { repair technical faults related to information } \\
\text { systems }\end{array}$ & 33 & $22 \%$ & 117 & $78 \%$ & 0 & $0 \%$ & 333 & 74.00 & $145.56^{*}$ & $\begin{array}{c}\text { 1st } \\
\text { Repeater }\end{array}$ \\
\hline 29 & $\begin{array}{l}\text { Means of communication and information } \\
\text { technology are sufficient to perform the } \\
\text { work of the Directorate of Youth and Sports } \\
\text { in the Sharkia province. }\end{array}$ & 18 & $12 \%$ & 108 & $72 \%$ & 24 & $16 \%$ & 294 & 65.33 & $101.28 *$ & 8 th \\
\hline
\end{tabular}

* Significantly different at $p<.(2,0.05)=5.99$

** Frequency

*** Percentage 
Table (9) shows statistically significant of value of $\mathrm{Ka} 2$ of sample response to axis: suitability of information systems in administrative development related to requirements of Six Sigma quality standards application at $\mathrm{p}<$. (2, $0.05)$, value of calculated $\mathrm{Ka} 2$ ranged between (15.24, 145.56), and value of relative weight ranged between phrases $(234,333)$.

Percentage of phrases answered (yes) ranged between $(12 \%, 42 \%)$, percentage of phrases answered (rather) ranged between $(20 \%, 82 \%)$, and percentage of phrases answered (no) ranged between $(6 \%, 62 \%)$.

Table (9) shows statistically significant of all phrases of axis: suitability of information systems in administrative development related to requirements of Six Sigma quality standards application, value of calculated $\mathrm{Ka} 2$ ranged between $(15.24,145.56)$ at $\mathrm{p}<.(2,0.05)$.

Researcher attribute this results to the support for the process of data collection, either internally or externally, but data collection have no effective communication to share data and information in the Directorate, effective training tools is not providing for employees to learn systematically of quality improvement in the Directorate, which does not help in debugging or directing performance.

Design for Six Sigma (DFSS) is a systematic methodology using tools, training, and measurements to enable the design of products, services, and processes that meet customer expectations at Six Sigma quality levels. DFSS optimizes the design process to achieve Six Sigma performance and integrates characteristics of Six Sigma methodology in product development (Westgrad, Hames O., 2002).

These results are on line with (Robbins, $\mathrm{Zu}$ Fredendall, 2006) that guidance is important for quality practitioners in Six Sigma. These results are on line also with (Rodeny - Stewart, 2006) that improving communication between staff members is one of applying Six Sigma requirements. Management Information Systems are one of elements which have a basic and important role in success of operation of applying Six Sigma (Antony, Bhaiji, 2003). 
Table (10)

Frequency, percentage, value of Ka2 and phrases rank of sample response to 4th axis: presence extent of teams work for administrative development related to requirements of Six Sigma quality standards application N=150

\begin{tabular}{|c|c|c|c|c|c|c|c|c|c|c|c|}
\hline \multirow[b]{2}{*}{$S$} & \multirow[b]{2}{*}{ Phrases } & \multicolumn{2}{|c|}{ Yes } & \multicolumn{2}{|c|}{ Rather } & \multicolumn{2}{|c|}{ No } & \multirow[b]{2}{*}{ 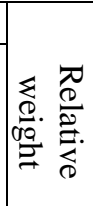 } & \multirow[b]{2}{*}{ 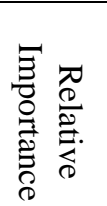 } & \multirow[b]{2}{*}{ 胥 } & \multirow[b]{2}{*}{$\begin{array}{l}\text { त्र } \\
\hat{\mathscr{E}}_{\pi}\end{array}$} \\
\hline & & $\underset{\substack{* \\
\overparen{T}}}{\stackrel{*}{*}}$ & $\underset{*}{*}$ & $\frac{*}{\stackrel{*}{*}}$ & 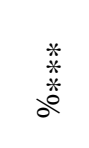 & 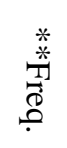 & $\begin{array}{l}\frac{*}{*} \\
\frac{3}{9}\end{array}$ & & & & \\
\hline 30 & $\begin{array}{l}\text { Teams are formed to develop certain } \\
\text { perceptions for performance quality in the } \\
\text { Directorate of Youth and Sports in the } \\
\text { Sharkia province. }\end{array}$ & 54 & $36 \%$ & 21 & $14 \%$ & 75 & $50 \%$ & 279 & 62.00 & $29.64 *$ & 5th \\
\hline 31 & $\begin{array}{l}\text { There are teams working at the Directorate for } \\
\text { administrative development have the } \\
\text { conviction of their work }\end{array}$ & 39 & $26 \%$ & 39 & $26 \%$ & 72 & $48 \%$ & 267 & 59.33 & $14.52^{*}$ & 9th \\
\hline 32 & $\begin{array}{l}\text { Trust between members of management } \\
\text { development performance working groups. }\end{array}$ & 60 & $40 \%$ & 24 & $16 \%$ & 66 & $44 \%$ & 294 & 65.33 & $20.64 *$ & 4th \\
\hline 33 & $\begin{array}{l}\text { Teams work of administrative development } \\
\text { Featuring goals commitment and values. }\end{array}$ & 39 & $26 \%$ & 51 & $34 \%$ & 60 & $40 \%$ & 279 & 62.00 & 4.44 & $\begin{array}{c}5 \text { th } \\
\text { Repeater }\end{array}$ \\
\hline 34 & $\begin{array}{l}\text { Team work members of administrative } \\
\text { development performance have multiple } \\
\text { specialties. }\end{array}$ & 66 & $44 \%$ & 24 & $16 \%$ & 60 & $40 \%$ & 306 & 68.00 & $20.64 *$ & $3 \mathrm{rd}$ \\
\hline 35 & $\begin{array}{c}\text { Team work members of administrative } \\
\text { development performance have a common } \\
\text { sense of responsibility towards the required } \\
\text { tasks. }\end{array}$ & 39 & $26 \%$ & 36 & $24 \%$ & 75 & $50 \%$ & 264 & 58.67 & $18.84^{*}$ & 11th \\
\hline 36 & $\begin{array}{c}\text { Team work members of administrative } \\
\text { development performance have effective and } \\
\text { dynamic leadership. }\end{array}$ & 30 & $20 \%$ & 57 & $38 \%$ & 63 & $42 \%$ & 267 & 59.33 & $12.36^{*}$ & $\begin{array}{c}\text { 9th } \\
\text { Repeater }\end{array}$ \\
\hline 37 & $\begin{array}{l}\text { There is effective communication between } \\
\text { Team work members of administrative } \\
\text { development performance in directorate. }\end{array}$ & 33 & $22 \%$ & 48 & $32 \%$ & 69 & $46 \%$ & 264 & 58.67 & $13.08 *$ & $\begin{array}{c}11 \text { th } \\
\text { Repeater }\end{array}$ \\
\hline 38 & $\begin{array}{c}\text { Team work members of administrative } \\
\text { development performance have insisted on } \\
\text { improving the decisions quality. }\end{array}$ & 24 & $16 \%$ & 75 & $50 \%$ & 51 & $34 \%$ & 273 & 60.67 & $26.04 *$ & 7th \\
\hline 39 & $\begin{array}{c}\text { Team work members of administrative } \\
\text { development performance willing to upgrade } \\
\text { members' skills. }\end{array}$ & 27 & $18 \%$ & 69 & $46 \%$ & 54 & $36 \%$ & 273 & 60.67 & $18.12 *$ & $\begin{array}{c}\text { 7th } \\
\text { Repeater }\end{array}$ \\
\hline 40 & $\begin{array}{l}\text { Availability of incentive structure and work } \\
\text { environment in spirit. }\end{array}$ & 33 & $22 \%$ & 30 & $20 \%$ & 87 & $58 \%$ & 246 & 54.67 & $41.16^{*}$ & 13th \\
\hline 41 & $\begin{array}{l}\text { Team work members of administrative } \\
\text { development performance have appropriate } \\
\text { levels of management. }\end{array}$ & 54 & $36 \%$ & 75 & $50 \%$ & 21 & $14 \%$ & 333 & 74.00 & $29.64 *$ & $1 \mathrm{st}$ \\
\hline 42 & $\begin{array}{l}\text { Issues are resolved better by team work } \\
\text { members. }\end{array}$ & 51 & $34 \%$ & 72 & $48 \%$ & 27 & $18 \%$ & 324 & 72.00 & $20.28^{*}$ & 2nd \\
\hline
\end{tabular}

\section{* Significantly different at $p<.(2,0.05)=5.99$ \\ ** Frequency \\ **** Percentage}

Table (10) shows statistically significant of value of $\mathrm{Ka} 2$ of sample response to axis: presence extent of teams work for administrative development related to requirements of Six Sigma quality standards application at $\mathrm{p}<$. $(2,0.05)$, except phrase number (33) no statistically significant, value of calculated $\mathrm{Ka} 2$ ranged between $(4.44,41.16)$, and value of relative weight ranged between phrases $(246,333)$.

Percentage of phrases answered (yes) ranged between $(16 \%, 44 \%)$, percentage of phrases answered (rather) ranged between $(14 \%, 50 \%)$, and percentage of phrases answered (no) ranged between $(14 \%, 58 \%)$. 
Table (10) shows statistically significant of all phrases of axis: presence extent of teams work for administrative development related to requirements of Six Sigma quality standards application, value of calculated $\mathrm{Ka} 2$ ranged between $(4.44,41.16)$ at $\mathrm{p}<.(2,0.05)$.

Researcher attribute this results to not holding preliminary sessions to spread improvement quality systems culture and active participation for workers in each stage and review processes, also weakness of a precise criteria ensuring good choice for teams work, administration urgency accessing results before completion of recommendations reduces chances of teams work success.

Six sigma methodology of problem solving integrates the human elements (culture change, customer focus, belt system infrastructure, etc.) and process elements (process management, statistical analysis of process data, measurement system analysis, etc.) of improvement (Antony, J.I., 2004).

These results are on line with (Antony, Bhaiji, 2003) that human resources have a basic and important role in success of operation of applying Six Sigma.

Table (11)

Frequency, percentage, value of Ka2 and phrases rank of sample response to 5th axis: cooperation departments and divisions extent to develop administrative development related to requirements of Six Sigma quality standards application $\mathrm{N}=150$

\begin{tabular}{|c|c|c|c|c|c|c|c|c|c|c|c|}
\hline \multirow[b]{2}{*}{$\mathrm{S}$} & \multirow[b]{2}{*}{ Phrases } & \multicolumn{2}{|c|}{ Yes } & \multicolumn{2}{|c|}{ Rather } & \multicolumn{2}{|c|}{ No } & \multirow[b]{2}{*}{ 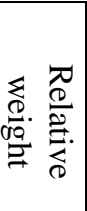 } & \multirow[b]{2}{*}{ 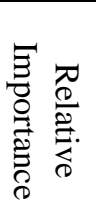 } & \multirow[b]{2}{*}{ त্র } & \multirow[b]{2}{*}{ 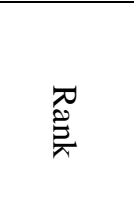 } \\
\hline & & 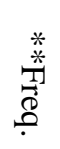 & $\begin{array}{c}\stackrel{*}{*} \\
\stackrel{*}{*} \\
\stackrel{*}{*}\end{array}$ & 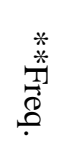 & $\begin{array}{c}* \\
\stackrel{*}{*} \\
\stackrel{*}{*}\end{array}$ & 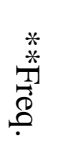 & $\frac{9}{3}$ & & & & \\
\hline 43 & $\begin{array}{l}\text { Social relationships between staff members } \\
\text { are close. }\end{array}$ & 12 & $8 \%$ & 129 & $86 \%$ & 9 & $6 \%$ & 303 & 67.33 & $187.32 *$ & 8 th \\
\hline 44 & $\begin{array}{c}\text { There is a sense of pride for departments' } \\
\text { enrolment which employee works. }\end{array}$ & 75 & $50 \%$ & 57 & $38 \%$ & 18 & $12 \%$ & 357 & 79.33 & $33.96 *$ & $1 \mathrm{st}$ \\
\hline 45 & $\begin{array}{l}\text { Satisfaction rate of other entities is high } \\
\text { while dealing with the Directorate. }\end{array}$ & 63 & $42 \%$ & 63 & $42 \%$ & 24 & $16 \%$ & 339 & 75.33 & $20.28 *$ & 2nd \\
\hline 46 & $\begin{array}{l}\text { New information is exchanged between } \\
\text { employees to develop work. }\end{array}$ & 21 & $14 \%$ & 75 & $50 \%$ & 54 & $36 \%$ & 267 & 29.33 & $29.64 *$ & 10th \\
\hline 47 & $\begin{array}{l}\text { Work environment works to remove } \\
\text { administrative and psychological barriers } \\
\text { between workers. }\end{array}$ & 36 & $24 \%$ & 87 & $58 \%$ & 27 & $18 \%$ & 309 & 68.67 & $41.88^{*}$ & 4th \\
\hline 48 & Workers opinions estimated and praised. & 36 & $24 \%$ & 84 & $56 \%$ & 30 & $20 \%$ & 306 & 68.00 & $35.04 *$ & 7th \\
\hline 49 & $\begin{array}{l}\text { Departments and sections of the Directorate } \\
\text { realize it's interrelated. }\end{array}$ & 21 & $14 \%$ & 102 & $68 \%$ & 27 & $18 \%$ & 294 & 65.33 & $81.48 *$ & 9 th \\
\hline 50 & $\begin{array}{c}\text { Competition spirit between workers creates } \\
\text { creativity. }\end{array}$ & 30 & $20 \%$ & 90 & $60 \%$ & 30 & $20 \%$ & 309 & 68.67 & $48.00 *$ & $\begin{array}{c}\text { 4th } \\
\text { Repeater }\end{array}$ \\
\hline 51 & $\begin{array}{l}\text { Departments and sections of the Directorate } \\
\text { Recognize the financial and technical } \\
\text { resources needs of each other. }\end{array}$ & 30 & $20 \%$ & 99 & $66 \%$ & 21 & $14 \%$ & 309 & 68.67 & $72.84 *$ & $\begin{array}{l}\text { 4th } \\
\text { Repeater }\end{array}$ \\
\hline 52 & $\begin{array}{c}\text { Directorate of Youth and Sports in Sharkia } \\
\text { have a cooperation spirit in work } \\
\text { completion. }\end{array}$ & 36 & $24 \%$ & 90 & $60 \%$ & 24 & $16 \%$ & 312 & 45.00 & $49.44 *$ & $3 r d$ \\
\hline
\end{tabular}

\section{* Significantly different at $p<.(2,0.05)=5.99$ \\ ** Frequency \\ **** Percentage}

Table (11) shows statistically significant of value of $\mathrm{Ka} 2$ of sample response to axis: cooperation departments and divisions extent to develop administrative development related to requirements of Six Sigma quality standards application at $\mathrm{p}<.(2,0.05)$, value of calculated $\mathrm{Ka} 2$ ranged between $(20.28,187.32)$, and value of relative weight ranged between phrases (267, 357).

Percentage of phrases answered (yes) ranged between $(8 \%, 50 \%)$, percentage of phrases answered (rather) ranged between $(38 \%, 86 \%)$, 
and percentage of phrases answered (no) ranged between $(6 \%, 36 \%)$.

Table (11) shows statistically significant of all phrases of axis: cooperation departments and divisions extent to develop administrative development related to requirements of Six Sigma quality standards application, value of calculated Ka2 ranged between $(20.28,187.32)$ at $\mathrm{p}<$. (2, 0.05).

Researcher attribute this results that workers' Directorate recognize the importance of cooperation between them in order to achieve the desired goals, this cooperation helps divisions and departments of the Directorate to identify financial and technical resources needs of departments.
Organizational culture is viewed as the pattern of values, beliefs, and assumptions shared by members in an organization, which are perceived by the organization as the valid, correct way to perceive and solve problems. These shared values, beliefs, and assumptions in the organization bind its employees together and become the manner or strategies through which the organization achieves its goals (Robbins, $\mathrm{Zu}$ Fredendall, 2006).

These results are on line with (Robbins, $\mathrm{Zu}$ Fredendall, 2006) in importance of organizational groups for quality practitioners in Six Sigma. 
The proposed operational plan for development of administrative Directorate of Youth and Sport in Eastern province related to requirements of Six Sigma quality standards application

\begin{tabular}{|c|c|c|c|c|c|}
\hline \multirow{2}{*}{ Aim } & \multirow{2}{*}{$\begin{array}{l}\text { Outputs } \\
\text { (Specific) }\end{array}$} & \multirow{2}{*}{$\begin{array}{l}\text { success indicators } \\
\text { (Measurable) }\end{array}$} & \multirow{2}{*}{ major activities } & \multicolumn{2}{|c|}{$\begin{array}{c}\text { Implementation } \\
\text { period }\end{array}$} \\
\hline & & & & Start & End \\
\hline \multirow{4}{*}{$\begin{array}{c}1 \text { - } \\
\text { Administrative } \\
\text { development } \\
\text { of directorate } \\
\text { through senior } \\
\text { management } \\
\text { contribution } \\
\text { and } \\
\text { departments' } \\
\text { cooperation of } \\
\text { the } \\
\text { Directorate. }\end{array}$} & \multirow{4}{*}{$\begin{array}{l}\text { 1/A, work } \\
\text { stimulating } \\
\text { environment } \\
\text { lead to } \\
\text { performance } \\
\text { efficiency. }\end{array}$} & \multirow{4}{*}{$\begin{array}{l}\text { 1- The efficiency and } \\
\text { effectiveness of the } \\
\text { organization's } \\
\text { performance. } \\
2 \text { - Plans to improve } \\
\text { the level of satisfaction } \\
\text { of employees. }\end{array}$} & $\begin{array}{l}\text { 1/A/1, reconfigure of departments in order } \\
\text { to fit their qualifications, job tasks, } \\
\text { workload and develop plans to deal with the } \\
\text { increase or decrease. }\end{array}$ & $1 \backslash 1$ & $30 \backslash 3$ \\
\hline & & & $\begin{array}{l}\text { 1/A/2, providing necessary equipment to } \\
\text { improve the working environment and } \\
\text { development of policies to link rewards with } \\
\text { performance. }\end{array}$ & $1 \backslash 1$ & $30 \backslash 4$ \\
\hline & & & $\begin{array}{l}\text { 1/A/3, survey ranks for future goals for the } \\
\text { process of determining authorities, } \\
\text { responsibilities and competences, clearly for } \\
\text { leaders and employees of the Directorate } \\
\text { and analysis of obtained results. }\end{array}$ & $1 \backslash 4$ & $30 \backslash 4$ \\
\hline & & & $\begin{array}{c}\text { 1/A/4, measure the level of satisfaction and } \\
\text { take immediate and effective steps to } \\
\text { enhance the strengths and weaknesses } \\
\text { points. }\end{array}$ & 115 & $30 \backslash 6$ \\
\hline & \multirow{4}{*}{$\begin{array}{l}\text { 1/B, plan for } \\
\text { specialized } \\
\text { services } \\
\text { departments' } \\
\text { development of } \\
\text { Directorate. }\end{array}$} & \multirow{4}{*}{$\begin{array}{l}\text { 1- Agendas and record } \\
\text { of committee meetings } \\
\text { and workshops. } \\
2 \text { - Completion of the } \\
\text { formation of } \\
\text { specialized } \\
\text { departments. } \\
3 \text { - Increasing of staff } \\
\text { satisfaction (70\%). } \\
4 \text { - Increasing of } \\
\text { satisfaction of } \\
\text { beneficiaries ( } 70 \% \text { ) for } \\
\text { specialized } \\
\text { departments for } \\
\text { directorate services. }\end{array}$} & $\begin{array}{c}\text { 1/B/1, a plan to develop specialized services } \\
\text { departments. }\end{array}$ & 112 & $30 \backslash 2$ \\
\hline & & & $\begin{array}{l}\text { 1/B/2, business workshop for workers to } \\
\text { discuss new formations. }\end{array}$ & $1 \backslash 3$ & $30 \backslash 3$ \\
\hline & & & $\begin{array}{c}\text { 1/B/3, self-study and presented to an expert } \\
\text { to determine the positions to be developed } \\
\text { to achieve the desired goals and a plan of } \\
\text { improving action for the administrative } \\
\text { development. }\end{array}$ & $1 \backslash 4$ & $30 \backslash 6$ \\
\hline & & & $\begin{array}{l}\text { 1/B/4, documenting administrative } \\
\text { processes after development and preparation } \\
\text { of a manual includes descriptions of each } \\
\text { process, procedures and distributed to } \\
\text { departments depending on the nature of } \\
\text { each process and the work of a } \\
\text { questionnaire analysis of the results } \\
\text { obtained. }\end{array}$ & $1 \backslash 7$ & $30 \backslash 8$ \\
\hline & \multirow{5}{*}{$\begin{array}{l}\text { 1/C Study to } \\
\text { determine the } \\
\text { extent of } \\
\text { management } \\
\text { efficiency for } \\
\text { utilization of } \\
\text { human } \\
\text { resources } \\
\text { availability. }\end{array}$} & \multirow{5}{*}{$\begin{array}{l}\text { 1- Agendas and record } \\
\text { of committee meetings } \\
\text { and workshops. } \\
2 \text { - Completion of } \\
\text { database }(70 \%) . \\
3 \text { - Improved job } \\
\text { performance }(70 \%) \text {. } \\
4 \text { - Administrative } \\
\text { leadership satisfaction } \\
\text { (70\%). } \\
5 \text {-Workers and } \\
\text { beneficiaries } \\
\text { satisfaction (70\%). } \\
6 \text { - A clear statistical } \\
\text { data. }\end{array}$} & $\begin{array}{l}\text { 1/C/1, Review of current data inventory of } \\
\text { qualifications and available expertise for the } \\
\text { distribution of available human resources to } \\
\text { the various departments of the Directorate. }\end{array}$ & 119 & $30 \backslash 9$ \\
\hline & & & $\begin{array}{l}\text { 1/C/2, held a workshop for beneficiaries to } \\
\text { determine the mechanism of information } \\
\text { access, statistics and constant updating. }\end{array}$ & 119 & $30 \backslash 9$ \\
\hline & & & $\begin{array}{l}\text { 1/C/3, business questionnaire to activate } \\
\text { reward and punishment policies, } \\
\text { environmental analysis and corrective } \\
\text { actions for adoption of specialized } \\
\text { departments. }\end{array}$ & $1 \backslash 10$ & $30 \backslash 12$ \\
\hline & & & $\begin{array}{c}\text { 1/C/4, held a workshop with beneficiaries to } \\
\text { activate amended reward and punishment } \\
\text { policies. }\end{array}$ & $1 \backslash 13$ & $30 \backslash 13$ \\
\hline & & & $\begin{array}{l}\text { 1/C/5, questionnaire to solicit the opinion of } \\
\text { management, and a sample of beneficiaries } \\
\text { to analyze the results and declared it. }\end{array}$ & $1 \backslash 16$ & $30 \backslash 17$ \\
\hline
\end{tabular}




\begin{tabular}{|c|c|c|c|c|c|}
\hline \multirow[t]{2}{*}{ Aim } & \multirow{2}{*}{$\begin{array}{l}\text { Outputs } \\
\text { (Specific) }\end{array}$} & \multirow{2}{*}{$\begin{array}{c}\text { success } \\
\text { indicators } \\
\text { (Measurable) }\end{array}$} & \multirow[t]{2}{*}{ major activities } & \multicolumn{2}{|c|}{$\begin{array}{c}\text { Implementation } \\
\text { period }\end{array}$} \\
\hline & & & & Start & End \\
\hline \multirow{4}{*}{$\begin{array}{c}2- \\
\text { Administrative } \\
\text { development } \\
\text { of the } \\
\text { directorate } \\
\text { through } \\
\text { training } \\
\text { availability. }\end{array}$} & \multirow{4}{*}{$\begin{array}{l}\text { 2/A, training } \\
\text { plan for } \\
\text { managerial } \\
\text { skills } \\
\text { development } \\
\text { for workers } \\
\text { and leaders } \\
\text { of the } \\
\text { Directorate. }\end{array}$} & \multirow{4}{*}{$\begin{array}{c}1 \text { - Specific } \\
\text { training } \\
\text { needs. } \\
2 \text { - Leaders } \\
\text { and workers } \\
\text { participation } \\
\text { in training } \\
\text { programs of } \\
\text { managerial } \\
\text { skills } \\
\text { development. } \\
3 \text { - } \\
\text { Performance } \\
\text { assessment of } \\
\text { trained } \\
\text { leaders and } \\
\text { workers. }\end{array}$} & $\begin{array}{c}\text { 2/A/1, workshops to identify the training } \\
\text { needs of leaders and workers of the } \\
\text { Directorate. }\end{array}$ & $1 \backslash 1$ & $30 \backslash 1$ \\
\hline & & & $\begin{array}{c}\text { 2/A/2, development of appropriate annual } \\
\text { training plan for management skills for } \\
\text { leaders and workers in order to develop their } \\
\text { skills. }\end{array}$ & 112 & $30 \backslash 3$ \\
\hline & & & $\begin{array}{l}\text { 2/A/3, performance evaluating of trained } \\
\text { leaders and workers through questionnaire } \\
\text { analyzes and feedback evaluation. }\end{array}$ & $1 \backslash 12$ & $30 \backslash 12$ \\
\hline & & & $\begin{array}{l}\text { 2/A/4, participations announcement of leaders } \\
\text { and workers in training programs for } \\
\text { managerial skills development, final } \\
\text { questionnaires results on the bulletin board } \\
\text { and website of the Directorate. }\end{array}$ & $1 \backslash 12$ & $30 \backslash 12$ \\
\hline
\end{tabular}

\begin{tabular}{|c|c|c|c|c|c|}
\hline \multirow[t]{2}{*}{ Aim } & \multirow{2}{*}{$\begin{array}{l}\text { Outputs } \\
\text { (Specific) }\end{array}$} & \multirow{2}{*}{$\begin{array}{c}\text { success } \\
\text { indicators } \\
\text { (Measurable) }\end{array}$} & \multirow[t]{2}{*}{ major activities } & \multicolumn{2}{|c|}{$\begin{array}{l}\text { Implementation } \\
\text { period }\end{array}$} \\
\hline & & & & Start & End \\
\hline \multirow{5}{*}{$\begin{array}{c}3 \text { - } \\
\text { Administrative } \\
\text { development } \\
\text { of the } \\
\text { directorate } \\
\text { through } \\
\text { appropriate } \\
\text { information } \\
\text { systems. }\end{array}$} & \multirow{5}{*}{$\begin{array}{c}\text { 3/A, } \\
\text { databases of } \\
\text { Directorate } \\
\text { related to } \\
\text { important } \\
\text { information } \\
\text { sites related } \\
\text { to sports } \\
\text { field. }\end{array}$} & \multirow{5}{*}{$\begin{array}{c}1 \text { - Data } \\
\text { acquisition } \\
\text { speedily. } \\
2 \text { - } \\
\text { Communication } \\
\text { and information } \\
\text { exchange } \\
\text { Easily between } \\
\text { various } \\
\text { departments of } \\
\text { the Directorate. }\end{array}$} & $\begin{array}{c}\text { 3/A/1, reviews of administrative, legal } \\
\text { information and existing databases of the } \\
\text { Directorate. }\end{array}$ & $1 \backslash 6$ & $30 \backslash 8$ \\
\hline & & & $\begin{array}{c}\text { 3/A/2, workshops to determine mechanisms } \\
\text { of information access and operation of this } \\
\text { system. }\end{array}$ & $1 \backslash 7$ & $30 \backslash 8$ \\
\hline & & & $\begin{array}{l}\text { 3/A/3, providing modern databases of } \\
\text { Directorate. }\end{array}$ & $1 \backslash 9$ & $30 \backslash 12$ \\
\hline & & & $\begin{array}{l}\text { 3/A/4 updates and creates of informative } \\
\text { rules and regulations as one of the controls } \\
\text { and announcing of Directorate. }\end{array}$ & $1 \backslash 10$ & $30 \backslash 12$ \\
\hline & & & $\begin{array}{c}\text { 3/A/5, Purchase modern communication } \\
\text { techniques, provision of manuals and } \\
\text { handbooks describes communication policy. }\end{array}$ & $1 \backslash 10$ & $30 \backslash 12$ \\
\hline
\end{tabular}

\begin{tabular}{|c|c|c|c|c|c|}
\hline \multirow[t]{2}{*}{ Aim } & \multirow{2}{*}{$\begin{array}{l}\text { Outputs } \\
\text { (Specific) }\end{array}$} & \multirow{2}{*}{$\begin{array}{c}\text { success } \\
\text { indicators } \\
\text { (Measurable) }\end{array}$} & \multirow[t]{2}{*}{ major activities } & \multicolumn{2}{|c|}{$\begin{array}{c}\text { Implementation } \\
\text { period }\end{array}$} \\
\hline & & & & Start & End \\
\hline \multirow{4}{*}{$\begin{array}{c}4 \text { - } \\
\text { Administrative } \\
\text { development } \\
\text { of the } \\
\text { directorate by } \\
\text { having teams } \\
\text { work to } \\
\text { develop } \\
\text { managerial } \\
\text { performance. }\end{array}$} & \multirow[t]{4}{*}{$\begin{array}{l}\text { 4/B, } \\
\text { Furnished } \\
\text { Quality } \\
\text { Management } \\
\text { Unit in the } \\
\text { Directorate. }\end{array}$} & \multirow{4}{*}{$\begin{array}{l}1 \text { - leadership } \\
\text { support for } \\
\text { quality } \\
\text { management } \\
\text { systems } 90 \% \\
2 \text { - Workers } \\
\text { satisfaction of } \\
\text { quality unit } \\
80 \% \text {. } \\
3 \text { - Increased } \\
\text { Cadres } \\
\text { participation } \\
\text { of quality unit } \\
80 \% \text {. } \\
4 \text { - Further } \\
\text { performance } \\
\text { improvement } \\
\text { of quality } \\
\text { management } \\
\text { unit } 80 \% \text {. }\end{array}$} & $\begin{array}{l}\text { 4/B/1, working groups to develop certain } \\
\text { perceptions of quality performance within the } \\
\text { Directorate, formation of Quality } \\
\text { Management internal units in the Directorate, } \\
\text { preparation of job descriptions for each job } \\
\text { and appointment of qualified cadres of } \\
\text { computers maintenance. }\end{array}$ & $1 \backslash 1$ & $30 \backslash 3$ \\
\hline & & & $\begin{array}{c}\text { 4/B/2, buy furniture, equipment and necessary } \\
\text { machinery for Quality Management } \\
\text { Directorate unit. }\end{array}$ & $1 \backslash 1$ & $30 \backslash 3$ \\
\hline & & & $\begin{array}{c}\text { 4/B/3, spread awareness among leaders and } \\
\text { workers of the Directorate for quality } \\
\text { administrative culture by holding seminars } \\
\text { and workshops. }\end{array}$ & $1 \backslash 4$ & $30 \backslash 9$ \\
\hline & & & $\begin{array}{c}\text { 4/B/4, held a workshop for leaders and staff } \\
\text { members of the Directorate to follow-up } \\
\text { support and commitment to implement rules } \\
\text { policies of procedure of the directorate } \\
\text { quality. }\end{array}$ & $1 \backslash 10$ & $30 \backslash 12$ \\
\hline
\end{tabular}


This proposed operational plan for development of administrative Directorate of Youth and Sport in Eastern province related to requirements of Six Sigma quality standards application answers 6th Hypothec.

\section{Conclusions}

$1^{\text {st }}$ axis: Senior management's contribution towards administrative development related to requirements of Six Sigma quality standards application:

1. There are seriously from senior management of the Directorate of disposing old ways and search for new sophisticated methods.

2. Modern technologies of senior management availability of the Directorate needed to raise performance level and business achievement.

3. Senior management encourages to get rid of unnecessary steps in the work.

4. Senior management gives the opportunity to participate in the efforts to improve performance.

5. Senior management put precise criteria to measure performance level.

6. Dependent senior management financial allocations to improve the quality of performance.

7. Senior management development praising the achievements at work.

8. Senior management reward outstanding in work.

9. Senior management benefit from developmental studies and visions for methods development of work on an ongoing basis.

10. Senior management does not allow dialogue in front of non-workers convinced modern methods of development and try to persuade them.

11. Senior management does not allow applications of modern and advanced administrative methods of the affiliated Directorate.

2nd axis: availability of training for administrative development related to requirements of Six Sigma quality standards application

1. There is no training plan for employees have been developed based on training needs of the Directorate.
2. Training Programs in Directorate related directly to the course of work.

3. Employees are encouraged at the different administrative levels to develop their own skills.

4. Workers were not trained on methods to improve the quality of performance.

5. Promotions are not linked with improving the quality of performance.

6. Not provided and creation of places to train workers.

7. Not provide qualified instructors to train employees in the directorate.

3rd axis: suitability of information systems in administrative development related to requirements of Six Sigma quality standards application:

1. Availability in the Directorate strong information and sophisticated infrastructure linked to all departments and divisions

2. Information Infrastructure contributes improving performance quality.

3. There are modern databases in Directorate help in making decision.

4. Work is done through computerized communication.

5. There is no ongoing review of information systems to correct mistakes.

6. There is no electronic network in Directorate helps in performance guiding.

7. There are alternative ways to get job completion in case of faults.

8. Directorate of Youth and Sports in Sharkia Used modern means of communication to report references for its regions.

9. Directorate have a human possibilities to repair technical faults related to information systems

10. Means of communication and information technology are sufficient to perform the work of the Directorate of Youth and Sports in the Sharkia province.

4th axis: presence extent of teams work for administrative development related to requirements of Six Sigma quality standards application

1. Teams are formed to develop certain perceptions for performance quality in the Directorate of Youth and Sports in the Sharkia province. 
2. There are teams working at the Directorate for administrative development have the conviction of their work

3. Trust between members of management development performance working groups are not a lot.

4. Teams work of administrative development Featuring goals commitment and values.

5. Team work members of administrative development performance have multiple specialties.

6. Team work members of administrative development performance have a common sense of responsibility towards the required tasks.

7. Team work members of administrative development performance have no effective and dynamic leadership.

8. There is no effective communication between Team work members of administrative development performance in directorate.

9. Team work members of administrative development performance have no insisted on improving the decisions quality.

10. Team work members of administrative development performance are not willing to upgrade members' skills.

11. Unavailability of incentive structure and work environment in spirit.

12. Team work members of administrative development performance have appropriate levels of management.

13. Issues are resolved better by team work members.

5th axis: cooperation departments and divisions extent to develop administrative development related to requirements of Six Sigma quality standards application

1. Social relationships between staff members are rarely close.

2. There is a sense of pride for departments' enrolment which employee works.

3. Satisfaction rate of other entities is rarely high while dealing with the Directorate.

4. New information is exchanged between employees to develop work.

5. Work environment works rarely to remove administrative and psychological barriers between workers.

6. Workers opinions estimated and praised rarely.
7. Departments and sections of the Directorate rarely realize it's interrelated.

8. Competition spirit between workers rarely creates creativity.

9. Departments and sections of the Directorate rarely recognize the financial and technical resources needs of each other.

10. Directorate of Youth and Sports in Sharkia have a rarely cooperation spirit in work completion.

Six Sigma as a powerful business strategy has been well recognised as an imperative for achieving and sustaining operational and service excellence. While the original focus of Six Sigma was on manufacturing, today it has been widely accepted in both service and transactional processes. Although the total package may change as part of the evolutionary process, the core principles of Six Sigma will continue to grow in the future. Six sigma has made a huge impact on management and yet the academic community lags behind in its understanding of this powerful strategy. It will therefore be incumbent on academic fraternity to provide well-grounded theories to explain the phenomena of Six Sigma. In other words, Six Sigma lacks a theoretical underpinning and hence it is our responsibility as academicians to bridge the gap between the theory and practice of Six Sigma.

\section{References}

1. Antony, J and Bhaiji, M. (2003): Key Ingredients for a Successful Six Sigma Program, Partnering Intelligence Newsletter, April issue, P: 5-25.

2. Antony, J.I. (2004): Six Sigma in the UK Service Organization Results from A Pilot Survey, Managerial Auditing Journal, 19, (8/9), 1006 - 1013.

3. Antony J, Downey-Ennis K, Antony F, Seow C. (2007): Can Six Sigma be the "cure" for our ailing NHS?, Leadership in Health Services, October, 20(4):242-53.

4. Burr, I.W.,(1996): Statistical Quality Control Methods, Mareel Dekker, USA, p: 56.

5. Grog Brue (2002): Six - Sigma for Managers, by Mc G-Hill press, p: 82. 
6. Hahn, G., Doganaksoy. N., Stanard, C., of Business Administration, University Of (2001): Statistical tools for six sigma, GE Tatung, Taipei.

research \& development centre.

11. Robbins, $\mathrm{Zu}$ Fredendall (2006):

7. Kai Yang and Basem S. Elhaik (2003): Organizational Culture and Quality Practices In Design for Six-Sigma, (Mc-Graw-Hill), P: 462. Six Sigma, 31 (5), 60-64.

8. Morgan, John (2006): Six Sigma and the future of quality management services", Pivotal Resources, USA.

9. Pande, P, Holpp, I, (2002): What is Six Sigma?, Mcgraw - hill, U.S.A., p: 115.

10. Pie - Shih, H.S (2006): The Effect Of Six Sigma Implementation, Practices On Business Performance, Master Thesis from Department 12. Rodeny - Stewart (2006): Six Sigma as a strategy for process improvement on construction projects, construction management and Economics, 24 (4), 339-448.

13. Wary, Bruce, Hogan, Bob, (2002): Why Six Sigma insecurities operation, Bank of America, USA.

14. Westgrad, Hames O., (2002):”A Six Sigma Design Tool", all rights reserved, USA. 